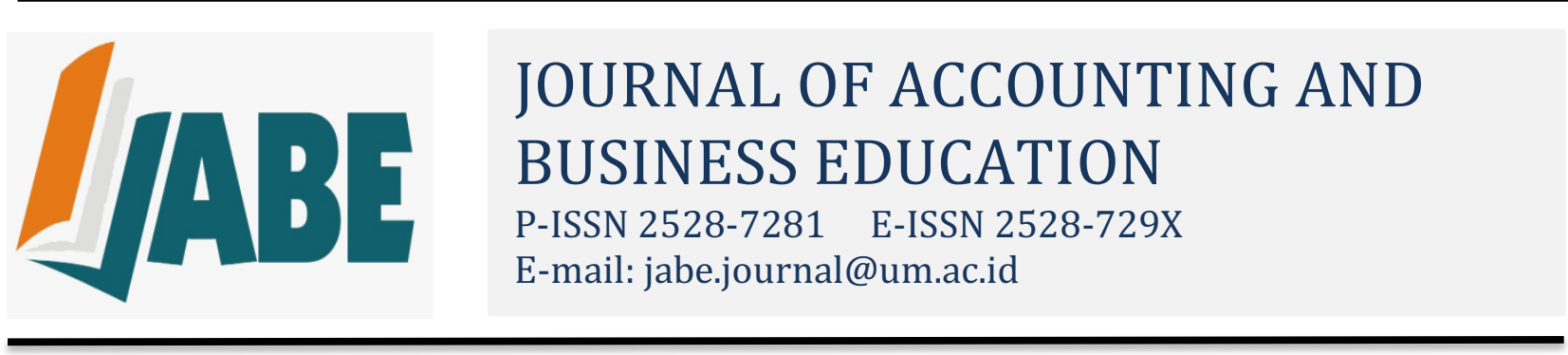

\title{
Analysis of Government Internal Control System on Budget Implementation in Accordance with Government Regulation No 60 of 2008
}

\author{
Muhamad Hafit \\ Gugus Irianto \\ Lilik Purwanti \\ Universitas Brawijaya \\ mhafid80180@gmail.com
}

\begin{abstract}
This study aims to analyze the implementation of Government Internal Control System (SPIP) in the implementation of the budget at the Office of National Unity and Politics (Kesbangpol) Batu City with reference to PP No. 60 of 2008. This research is a qualitative research using descriptive approach and case study strategy. The results showed that the implementation of SPIP in the implementation of the budget in Kesbangpol Office still has not run maximally in accordance with PP Number 60 of 2008, this is indicated by the unfulfilled SPIP element as a whole. Among others: 1) No complete job description; 2) no mapping and documentation of risks impeding the implementation of SPIP; 3 ) there is no review on the performance of Kesbangpol Office; 4) information technology applications that are still not functioning maximally, and 5) Follow up monitoring by APIP that has not been paid attention maximally.
\end{abstract}

Keywords: control system, government internal control system, the implementation of the budget

\section{INTRODUCTION}

The passion to reform our bureaucracy as written in the 1945 Constitution is interpreted as re-arrangement of governmental system enforced by civil servants in all government institutions, the regional and central government (sedarmayanti, 2009:113-114). State Ministry of Efficient Utilization of State Apparatus (Kemenpan) mentions reforming our bureaucracy means the effort to create basic renewal and change to our governmental system which emphasized on several points, they are a business process, organization, and human resources (http://www.menpan.go.id). The enforcement of governmental system emphasized on that 3 points as the main topic of the bureaucracy reformation is the main points to implement accountability and transparency principles which are part of Good Governance. That enables 
every policy to be accessed and held accountable to the public, in order to make society get involved in controlling and supervising the incumbent government.

Good Governance is a form of government administration which prioritizes the concept of clean, democratic, and effective government in giving its services to society. As a result of an increase in social knowledge, improvement on information and communication system, Good Governance has been important since there is global demand for efficient and effective government administration. To create Good Governance with high accountability is not easy, there should be solutions for every problems and obstacle that may appear. All of the problems and obstacles that hamper government administration can be repaired to create an ideal government. That is why a reformation on bureaucracy is intended to increase civil servants' accountability and transparency in giving their services.

Fast global changes in all part of life which include the development of knowledge, strategic environment, and technology of information, demands changes on government administration as well as its financial administration. Comprehensive, systematic, and basic steps have to be taken in order to create accountable and transparent financial administration. All of the problems and obstacles that hamper government administration can be repaired to create an ideal government. That is why a reformation on bureaucracy is intended to increase civil servants accountability and transparency in giving their services.

The accountable and transparent system of financial administration is significant for regional financial administration. That will happen when all government component completed their control of planning, implementing, supervising, and ordered, managed, effective, efficient accountability. Thus, there is a need upon a system that will help the enforcement of every government institutions achieve its goal effectively and efficiently, report local financial management reliably, safe local asset, encourage obedience toward current laws and regulations. The regulation which regulates internal control on the public sector is in Law No 1 of 2014. In order to boost performance, accountability, and transparency of local financial administrator, the head of a region regulate and enforce an internal control system in every regional government area he leads. That is regulated in Government Regulation No. 58 of 2005 article 134 paragraph 1. 
The internal control system mentioned specifically regulate in Government Regulation No. 60 of 2008 about SPIP. The main objective of internal control system creation is to achieve efficient, effective, accountable, transparent state financial system. SPIP has a significant role to prevent the main risk like extravagant, fraud, manipulation, and mismanagement (Rizal,2011). The use of SPIP in a good government administration is expected to create a Good Governance. That condition is expected to create an accountable local financial government which is shown from implemented vision and mission and regional government objectives; reliable financial report by obtaining unqualified opinion; lessening the chance of corruption, manipulation of authority, collusion and nepotism within the enforcement of governmental budget.

One of the indicators successful government control is by looking at the ability to absorb the designated budget within Provincial Budget $(A P B D)$. A controlled organization is the one which can do what has been planned by its leader and all members, also can be held accountable. By the ability of budget absorption in Office of National Unity and Politics (Kesbangpol) has failed to manage the budget since the absorption was late and not in accordance with its plan. It shows government failure to control its organization scope and makes the SPIP regulates in Government Regulation No. 60 of 2008 does not work to the fullest extent.

The late budget absorption early in of and the significantly fast budget absorption late of of make Kesbangpol office become an interesting subject for researchers related to SPIP on budget implementation. Kesbangpol office is also one of the significant parts of Batu City government that can help its Mayor achieve their vision and mission. Based on an Audit Report (LPH) Batu City Inspectorate for Kesbangpol office, the SPIP on the budget implementation and accountability become the main point the need to be repaired. Based on the explanation above, the researchers are interested to investigate and comprehend the implementation of Government Internal Control System $(S P I P)$ in the budget implementation at Kesbangpol office Batu City.

\section{LITERATURE REVIEW AND HYPOTHESES}

\section{Internal Control System}

Generally, internal control is part of every system used as operational procedure and guideline in a particular corporation or organization. Most of the corporations use Internal Control System to guide its operation and to prevent manipulation of the system. That terms refer 
to processes that happen within an entity (organization, including corporations), affected by the board of commissioners (or similar to board of supervisors), management, and other personals, which designed to give a guarantee in order for the entity can get its objectives. Entity's objectives are divided into 3 parts (COSO, 2013): 1) Effectiveness and efficiency of the operations. 2) Dependability, security, credibility or reliability of the financial report. 3) Compliance and disciplinal upon applicable laws and regulations.

The internal control functions are to find and prevent any manipulations, also to protect assets of an organization that is concrete (for instance, stockpile, asset [wealth], and treasury) or not concrete (for instance, reputation (good name), trademark, and intellectual property right). Application and implementation guideline of internal control have been formulated since 1985 in the United State of America, by Committee of Sponsoring Organization of the Treadway Commission (COSO). COSO was supported by five big organizations in the United State of America, which are American Accounting Association (AAA), American Institute of Certified Public Accountant (AICPA), Financial Executives International (FEI), The Institute of International Auditor (IIA), and Institute of Management Accountant (IMA).

The implementation guideline of internal control formulated by COSO is comprehensively used in many sectors, in public or private sectors. The concept or idea of internal control is intricately linked to calculation and accountancy which can be seen from its definition that is processes estimated to give a guarantee on the achievement of organization's objectives through the effective and efficient program, reliability, and accountability of financial report, also compliance upon applicable laws and regulations. As what Moeller (2007:4) says:

Internal control is a process, affected by an entity's board of directors, management, and other personnel, designed to provide reasonable assurance regarding the achievement of objectives in the following categories:

- effectiveness and efficiency of operations,

- reliability of financial reporting,

- compliance upon applicable laws and regulations

\section{Government Internal Control System (SPIP)}

Government Regulation No. 60 Year 2008 explains that Internal Control System (SPI) is processed referring to continuous and integrated behavior of leaders and its employees in order 
to achieve organization's objectives as a result of effective and efficient activity, reliability and accountability financial report, security of assets or state's assets, and also compliance upon laws and regulations. Government Internal Control System (SPIP) is an Internal Control System that is implemented in all governmental area. All of the activities, reviews, audits, monitors, evaluations, and other supervision acts for organization's main duties and functions to make all the processes enforced effectively and efficiently in accordance with its benchmark for the leader's interest to create a good governmental system.

In Government Regulation No. 60 Year 2007 there are several principals about Government Internal Control System (SPIP) related to the whole activities that are affected by human resources, which only gives the confidence to accomplish its objectives, but not absolute. Driteny (2016) explains that in order to comprehend the meaning of SPIP we need to comprehend several definitions below: 1) Criteria of SPIP enforcement is processes which are acts and activities done by the leader and all of the employees. That explained SPIP is an integrated process of acts and activities done by all of the members, from the superiors to the subordinates. In order to build a SPIP, there is the need to understand several processes of governmental enforcement management in all levels and priorities of controls. The implementation of SPIP on acts and activities is expected to bring economic, effective, and efficient development of SPIP. Regularly implemented processes by all parts of the organization are the main criterion of SPIP application. The applications of SPIP is not only used to fulfill a regulation, but it has to be implemented as a control culture as part of working culture in organizations. 2) Criteria of the main objectives of the SPIP implementation is to give confidence upon achieving organization's objectives. In order to unfold the objective of SPIP we need to see SPIP definition within Government Regulation No. 60 Year 2008. Within that regulation the confidence as the objectives of SPIP can be seen from: a) Effective and efficient activities, b) reliable and accountable financial report, c) Secure assets and state's assets d) compliant upon laws and regulations. 3) Criteria of the actor who implement SPIP is implemented in the level of superior and all of the worker, and also thoroughly implemented in the central and regional government. This variable explained that SPIP has been implemented by all of the civil servants in central and regional government. That is why the mandate to implement $S P I P$ is given to every person in every position.

In the article 13 paragraph 2 No 60 Year 2008, there are five elements of SPIP: 
1. The control area is implemented by the leader of each government institutions which are the foundation of SPIIP, through:

a. Enforcement of integrity and honesty within every action and remark reflecting the basic code of conduct.

b. Commitment toward skill or ability in order to not rely on one particular person.

c. Safe and conducive leadership.

d. Formation of organization structure based on its needs.

e. Proper distribution of assignment and delegation.

f. Creation and implementation of good policies on human resources development.

g. Application of supervision officers which are effective and efficient.

h. Proper and conducive relation with related Government Institutions.

2. Risk Assessment

Risk assessment is related to the established objectives set by government institution to make every financial related activities can be well manage. We do it because risk is about uncertainty.

3. Activity control

The characteristics of activity control implementation are:

a. Activity control is primarily implemented during compulsory and main activities of Government Institutions;

b. Activity control has to be interrelated with risk assessment;

c. Activity control has to be selected based on the government Institution;

d. Policies and procedures are written;

e. Approved and agreed procedures have to be implemented based on the written regulation;

f. Activity control is regularly reviewed and evaluated to ensure that the activities are implemented as it is planned.

4. Communication and Information

Communication and information is a way for superiors, working method, and subordinates interact to achieve the established working objectives. Effective communication and information have to be implemented. That can only be done if superiors provide, use, continuously and regularly update every means of communication (article 42 Government Regulation No 60 Year 2008). 


\section{Supervision}

The supervision of Internal Control System within Article 43 Government Regulation No 60 Year 2008 paragraph (1) is applied with separate evaluation, continuous supervision, and follow-up from audit and review report. Supervision is a reflection from continuously implemented activity control in particular government institution.

\section{Management of Regional Revenue}

In order to create good governance within the organization of a country or region, a good management of revenue needs to be well implemented professionally, accountable, publicly in central or regional level in accordance with the applicable laws and regulations. Before the reformation of state or regional revenue management, regional governments used Decree of Minister of Home Affairs (Kepmendagri) 29 Year 2002 about accountability and supervision of regional revenue and also provincial budget preparation guideline. The regional revenue administration and calculation of provincial budget preparation used as the guideline to manage the revenue. But eventually, there are many aspects to be improved from the decree, especially related to the publication of three regulation which marks the reformation of regional revenue management. One of the aspects is detailed explanation on administrative system and procedure (including the accounting), (Nilawati, 2009).

As the improvement of Decree of Minister of Home Affairs (Kepmendagri) 29 Year 2002, Ministry of Home Affairs Regulation 13 Year 2006 (Permendagri) was published. Other than comprehensive preparation or budgeting, administration, accounting, reporting, and accountability of regional revenue which is consistent with state revenue, one of the significant changes made by the decree is within the implementation, administration, reporting, and accountability of regional revenue, there is bigger responsibility given toward local government agency $(S K P D)$ as the budget user and implementing agency of the program.

\section{METHODS}

This research is descriptive analytic research uses qualitative approach and case study on Kesbangpol office Batu City. This research is carried out by collecting data, displaying data gathered from interview, literature and field observation, analyzing and interpreting by giving conclusion. It aims to gather detailed picture of the implementation of Government Internal 
Control System in accordance with Government Regulation No 60 Year 2008 in order to improve its budgeting. Qualitative research is used to gather understanding by a number of individuals or groups originated from social or humanity problems (Creswell, 2010:4; Noor, 2009:32).

In relation to time and place, specific object which can be deemed as a case is contemporary, it is and has been happening, yet still has significant and special impact and effect the moment the research is conducted (Yin, 2009:14).

The researchers took a technique found by Miles and Huberman (2009:20) because it is flexible and can be implemented in this research. The analysis of quantitative data was done continuously and thoroughly. These are the steps used in the data analysis: first, the data gathered through observation, interview, and documentation focused on the implementation of SPIP within budget application;

Table 1. List of Informants

\begin{tabular}{|l|l|l|}
\hline No & Name & Position \\
\hline 1 & Thomas Maydo, S.sos & Head of Kesbangpol office Batu City \\
2. & Sri Wuryantini & Head of Administrative Division \\
3. & Drs. Gatot Suyanto & Head of Inter-Institutional Body \\
4. & Suyono, SH & Head of Home Affair Politic Division \\
5 & Sugiarso, A.md & Head of State Integrity Division \\
6 & Drs. Saiful Mustofa, M.Si & Assistant Lieutenant Area II \\
\hline
\end{tabular}

Source: Office of National Unity and Politics (Kesbangpol) Batu City

Second, data reduction, the data are summarized, sorted out, and focused on the most important part in order to find a pattern related to the topic. Data reduction is a process to sort out, choose, summarize, focus, and simplify the abstract, and also to transform the raw data we have gotten. It resulted into specific depiction that help researchers find additional data if it is needed. By the more data we get, there will be more complicated and complex data analysis we need. Data reduction helps the researcher to avoid that situation. Third, data display, data display can be done by providing short narrative, chart, inter-category and many others. Data display is directed to organize data reduction in order to make it understandable. The researchers use a technique found by Miles and Huberman (2009:20) because it is flexible and can be implemented in this research. Qualitative data analysis is done continuously and thoroughly. The last step is drawing conclusion and verifying all data gathered, reduced, and displayed as result 
of the research. The conclusion will answer the initial research question. It is also expected to be a new finding.

\section{RESULTS}

Budget Implementation Report $(D P A)$ is document contains detailed information about budget absorbed by its user as the principle of budget implementation at Kesbangpol Office Batu City. DPA is a translation from Provincial Budget, it contains detailed program, financial resource, account code, and amount of the budget needs for the program. It also provides indicators and benchmarks for every program.

As explained by Mahmudi (2010:18-19) that a result of planned provincial budget approved by House of Representative is provincial budget which is specified into Budget Implementation Report (DPA) that includes: attainable targets, name of the program/activity, budget needed, and estimated income that can be a contribution for the budget implementation phase. Kesbangpol 2016 budget ceiling is Rp. 5.117.002.710,- to fund 11 programs/39 activities. On 2016, it got Rp. 7.407.287.680,- as its budget ceiling to fund 7 programs/28 activities.

\section{Government Internal Control System (SPIP) on Budget Implementation}

The result of observation and documentation show that supporting infrastructures as written in Government Regulation No. 60 Year 2008 about SPIP have not been created. There is only an Internal Control System regulation on procurement of goods and services as written in Mayor of Batu City Regulation No 9 Year 2014 about internal procurement system of goods and services within its area. As a copy of Government Regulation No. 60 Year 2008, it should not only cover internal control system on procurement of goods and services, but the whole government process starting from planning, implementing, holding accountability, and evaluating.

On the process of SPIP improvement, every Local Government Agency (SKPD), including Kesbangpol Office Batu City, have to create its Standard Operating System (SOP). However, according to Assistant Lieutenant II Inspectorate of Batu City interview, some government agencies still have not had complete SOP.

SPIP can be used to supervise the progress of an activity implementation, its management and its compatibility to the objectives. Besides, it can also be used to detect unpredicted obstacle 
within activity implementation. The supervision and evaluation process within SPIP can help to find immediate solution for the obstacle to lessen the possibility of failure. Implementation of internal control within every government agency is an integral part of the whole SPIP that includes: control area, risk assessment, activity control, information and communication, and supervision.

In control area, there are 8 elements that have to be fulfilled, they are: a) Wellimplemented enforcement of integrity and code of conduct. This is marked by ethical value adhered by people and Government Regulation No 53 Year 2010 about civil servant disciplinary. b) Commitment toward skills will be gained easily on the recruitment process, by right allocation of prospective employee based on their education level and skill. That has been regulated in Government Regulation No 8 Year 1974 about principal of employment which later changed into Law No. 43 Year 1999. c) Conducive leadership built from warm communication with its subordinates in order to improve performance. d) Formulate organization structure in accordance with Mayor of Batu City Regulation No 48 Year 2013 about main duty and function of Kesbangpol office. e) Distribute proper responsibility and authority as regulated in Mayor of Batu City Regulation No 48 Year 2013. Every responsibility and authority given are accompanied with official letter of duty or decree from head of the office. However, the reveals that some of the officer of Kesbangpol office have clear job description. It does not correspond Government Regulation No 60 Year 2008, particularly article 9. Job description is a guideline to implement budget from an organization. f) Formulate and implement right policies on human resources development by promotion of an officer who has fulfill the requirements. g) Externalize effective government internal control through conducive activity control. h) Good corporation with related government institutions like Education Agency, Health Agency, Office of District Prosecutor, and etc.

In risk assessment, internal control has to give assessment toward internal and external risk of an organization within budget implementation process through: a) Unmapped and undocumented risk identification and analysis within budget implementation are given to the person in charge of every activities. b) Risk analysis is done during coordination meeting in order to find solution for every problem appears within budget implementation process.

In activity control, there should be: 1) Review of Kesbangbol office Batu City performance on unimplemented internal budget. 2) Human resources development through 
giving reward for officer who has made an achievement in their main duties and function in form of promotion and giving punishment in form of oral warning from superiors or immediate notification from inspectorate. 3) Physical control toward registered and documented asset in accordance with Ministry of Home Affairs Regulation No 17 Year 2007 about technical guideline of regional asset control. 4) Establish and review performance and its indicators based on indicator of strategic target and performance (Renja 2015 and Renja 2016). 5) Isolation of function is done based on each main duties and functions explained in Mayor Regulation No 48 Year 2013 about detailed duties and function of Kesbangpol office Batu City. 6) Authority on transaction and other important occasions is given to Officer of Technical Activity (PPTK) as an accountable body of particular activity with the help from treasurer assistant in every expenditure administration in accordance with Ministry of Home Affairs Regulation No 13 Year 2006. 7) Accurate register of every transactions and important occasions. Written and electronic documentation of transactions and important occasion are done thoroughly and accurately in order to enable search (book of general treasury). 8) Limit access on resource and its register are periodically reported to the related bodies. 9) Accountability of the resource register is adjusted with system application and product (SAP). 10) Right register on loss, important occasions and transactions.

In information and communication, the provision and use of every means of communications made by Office for Management of Regional Revenue, Finance and Assets (DPPKAD) use to smoothen the disbursement of fund. Assets Management System of City of Batu (Simakoba), to manage the asset, and Regional Geopolitics and Intelligent System (Siagida) made by Asset and Supply of Regional Secretariat used to manage the development of regional politics and intelligent. At the time the research was conducted the systems were being repaired.

In supervision, there should be direct monitor and observation from superiors or coordination between related heads of divisions. In the coordination, every divisions supervise each other by giving input on problem that appears in particular activity. Supervision is formed by the surrounding, in the other hand, the surrounding directs it.

Supervision on budget implementation is also done by the office internally and also government internal control officers, in this case, is Inspectorate of Batu City or external body like Finance and Development Supervision Body $(B P K P)$ and Finance Auditor Body $(B P K)$. 


\section{DISCUSSION}

\section{Budget Implementation}

The amount of absorption from budget implementation can be seen from Budget Realization Report ( $L R A$ ) made by Outcome Treasurer. Outcome treasurer submit $L R A$ in every quarter and semester to Office for Management of Regional Revenue, Finance and Assets (DPPKAD). According to Kesbangpols's LRA in 2016, there is an increase on the budget absorption in first semester from 28,76\% in 2015 become 33,34\% in 2016. The budget surplus (SILPA) in 2015 is Rp. 345.607.024,- which signifies unfulfilled target of budget absorption.

As explained by Bastian (2007:387) that Budget Realization Report gives estimation of discrepancy between the amounts of budget and the budget absorbed. It shows financial activities of government which are obedience to Provincial or State Budget. It explains allocation, summary of resources, and also the utilization of resources managed by government in a period.

\section{SPIP on Budget Implementation}

In order to accomplish its vision, mission, and for the accountability of every government activities, all member of the organization, from the superiors to the subordinates, have to implement elements of internal control. To ensure that internal control system has been wellplanned, well-implemented, adequately upgraded to adapt to the condition, there should be continuous supervision. Government Regulation No 60 Year 2008 article 43 mentions that heads of government institutions have to supervise through separated assessment toward its internal control in order to know the performance and effectiveness of its internal control, and way to develop it. The internal control also can be used to identify and resolve the main risk like extravagant, fraud, manipulation, and mismanagement.

Every Government agency has to formulate a Standard Operating System. That is to develop SPIP. However, at the time, the research was conducted, Kesbangpol office did not have a complete SOP. There were only 3 SOP which are, SOP to give political assistance, SOP to give license of survey/internship/community service assignment, and SOP to register nongovernmental organization. According to explanation given by Mr. Saiful Mustofa, Assistant Lieutenant Area II of Inspectorate of Batu City, SOP should be made for every activities and main duty and functions of a government agency. SOP is made for supporting instrument of internal control system to control budget implementation works as it planned. 
As what Moeller (2007:4) explains that internal control is integrated process on repeated activities by the whole component of an organization to create adequate confidence to achieve its vision, mission, and objectives, through effective and efficient activities, security of state assets, reliable budget report, and compliance upon applicable laws and regulations. That is why, implementation of SPIP on budget implementation needs support from all control elements which are control are, risk assessment, activity control, information and communication, and supervision.

In control area, according to the result of interview, observation and document study, enforcement of integrity and code of conduct has been good. It is signified by consistency on behavior and ethical value adhered. As civil servant ethical value that should be uphold is Government Regulation No 53 Year 2010 about civil servant disciplinary.

In the commitment toward skills, it says that competent human resource is needed in budget implementation. This competent will be easily gained during the recruitment process, by right allocation of prospective employee based on their education level and skill. That has been regulated in Government Regulation No 8 Year 1974 about principal of employment which later changed into Law No. 43 Year 1999. There are 5 structural position in Kesbangpol office that have been filled by competent individuals.

From the result of interview with the head of Kesbangpol office, it can be estimated that there are efforts from the head of Kesbangpol office to build communication with all of the officer. It is done in warm manner in order to improve the performance. By comprehending members' needs and urges, a conducive circumstance has been built in order to improve budget implementation.

Formation of organization structure has been done by Kesbangpol office in accordance with Mayor of Batu City Regulation NO 48 Year 2013 about main duties and functions of Office of National Unity and Politics (Kesbangpol) Batu City. The formation is based on need assessment of the organization in giving services to people.

In relation to distribution of authority and responsibility, every position has main duties and functions that have been regulated in Mayor of Batu City Regulation No 48 Year 2013. Every responsibility and authority given are accompanied with official letter of duty or decree from head of the office. For instance, decree from head of the office on financial administration is given to treasurer, government institutions' officer of revenue management, goods recipient 
officer, goods storage officer, goods/services procurement, and etc. Even if, all of Kesbangpol officers relatively have their own job description, there are only several positions which have complete and detailed job description. It is not consistent with Government Regulation No. 60 Year 2008, especially article 9. Job description is guidelines given by organization to its members in doing budget implementation. The more vivid job description given will make it easier for members of the organization to implement its budget according to the plan.

In the right creation and implementation of the policies about human resources development is like promotion given to officer who has had integrity and fulfilled the requirements. It is to stimulate every officer in doing their duty, as what have been regulated in Law No 5 Year 2014 about civil servants.

Conducive control area implemented by government internal control officers which gives guidance to management of budget, employment, and regional assets. Besides, in doing its programs/activities Kesbangpol office needs corporations with related institution like Education Agency, Health Agency, Office of District Prosecutor, and etc. That corporations can be in the form of creating socialization on nationalism act, socialization to prevent drug trafficking, corporation on intelligent in the form of Regional Intelligent Community (Kominda), and Regional Governance Forum (Forpimda).

According to the result of observation, interview, and documentation that have been conducted by the researchers on the control area, the researchers found some sub-element that have not been fulfilled. They are there is no complete job description, especially for assistant staff who help in budget implementation, and there is no documentation on budget implementation review.

The risk assessment describes assessment on every obstacle hampers budget implementation in Kesbangpol office. Risk assessment emphasizes on internal control that has to give evaluation to every risk faced by Kesbangpol office in implementing the budget.

Based on the result of observation, interview, and documentation that have been conducted by the researchers, the researchers found that every budget implemented in Kesbangpol office always followed by risks. It is supported by statements from several head of divisions that said there is always risk in every budget implementation process. There has never been well-mapped and well-documented risk assessment before. As explains by Djohanputro (2008:43) risk 
management is a structured and systematic process to measure, identify, document, map, and develop a solution to handle the risk, supervise, and control the solution.

The activity control, from the result of observation, interview, and documentation the researcher knew that activity control on budget implementation was done through evaluation on activity report made by Officer of Technical Activity (PPTK) after the budget implemented. Evaluation on the report done to ensure the activity was done based on its main duties and functions given. The result of research on internal review on activity control in Kesbangpol office shows that internal review on officers' performance has not been conducted. The review is only to fulfilled government internal control annual request. Human resource development was done by giving reward to officer with achievement and punishment for officer with violation. The rewards were given in the form of promotion and education/training prepared in Government Institution's Budget Implementation Report. While the punishment is given in the form of oral or written warning from immediate superiors or inspectorate. Reward and punishment are strategies used by superiors to improve subordinates' performance in implementing budget at Kesbangpol office.

Management of information system to support budget implementation was controlled by one officer pointed as accountable operator to do network maintenance. Physical control on assets used to support budget implementation is done through assets management regulate in Ministry of Home Affairs Regulation No 17 Year 2007 about technical guideline to manage regional assets which is by inventorying its assets and later make the inventory cards A-F (for equipment and machines, land, irrigation way and network, buildings, ongoing construction, room inventory cards, and other permanent asset), direct codification on physical asset and room inventory cars for moving asset.

Isolation of functions in budget implementation is done in accordance with each main duties and functions. Isolation of function can be seen from organization structure in Mayor of Batu City Regulation No 4 year about main duties and functions of Kesbangpol office Batu City, which regulates every head of Kesbangpol will have 1 head of administration division and 3 head of other divisions (divisions of Home Politic, State Integration, and National Knowledge).

Authority for transactions and important occasions in budget implementation is given to Officer of Technical Activity (PPTK), government institutions' officer of revenue management $(P P K-S K P D)$, and outcome treasurer. PPTK helped by assistant treasurer in administrating, 
writing the register, and documenting the expenditures to support activities on divisions. $P P K$ $S K P D$ registers every cash transactions, expenditures, obligations, based on evidences submitted by assistant treasurer. The register is done accurately, on time, and up to date in accordance with Government Accounting Standard $(S A P)$. Outcome treasurer prepares documents and transactions related to accounting activities in SKPD. The register is transformed periodically into accountable, transparent, and well-documented report.

Reports on budget absorption and performance based on its indicators has been decided, while the priority is in reports based on the activities/programs. From an interview with Mr. Thomas Maydo, he explained that activities reports were made by divisions who were being the executive officer of the program. The reports used as sources of evaluation whether the program/activity was successful based on set indicators.

For the Information and communication, the result of interview, observation, and documentation explained that means of information and communication used by Kesbangpol office to support budget implementation is Simda. Simda is an online and integrated financial system. It is connected Kesbangpol office with Office for Management of Regional Revenue, Finance, and Assets $(D B B K A D)$. The other systems are Assets Management System of City of Batu (Simakoba) which is used to manage regional assets related to Regional Secretariat Supplies Body and Regional Geopolitics and Intelligent System (SIAGIDA) use to manage the development of regional politics and intelligent. Through good system, report can be submitted on time and with high level of accuracy.

On the information systems used in Kesbangpol, there has always been updated in accordance with the needs. The update always follows with training for its operators. The report from information system can be well-published. The report also uses as the source of evaluation in order to get future plan.

That is in line with Yuwono ideas (2005:19) that controls are done by accounting system using accounting information system and other modified computer applications to get more reliable information and effective communication through provision and utilization of many means of communication, management, and continuous development.

As the result of observation, interview, and documentation done by the researcher revealed information and communication system has been well-managed, especially Simda and Simakoba. The systems help to provide information related to budget implementation, thus make SPIP can 
make budget implementation become easier. It is supported by research finding that every system has integrated program to make ease the budget implementation. Besides, continuous management, development, and renewal of the system information can update every working part. However, Siagida a system made by Kesbangpol still cannot be well-utilized because of the need of repairmen on the current system.

Supervision, based on interviews it found out that supervision on budget implementation in Kesbangpol office was in the form of direct supervision from the superiors and supervision in the form of coordination on every divisions by giving suggestion and notification. Direct notification from head of office to head of divisions or head of divisions to the staff is applied if they need particular information. Communication in the form of reminder is also a control from the surrounding and also an early supervision.

Internal supervision toward budget implementation at Kesbangpol office is done by the head of the office himself, and also by government internal control officer which is Inspectorate of Batu City in this case, while external supervision is done by Finance and Development Supervision Body $(B P K P)$. Mrs. Sri Wuryantini said that monitoring and evaluation process is done internally and gradually at Kesbangpol office, from the superiors to subordinates, between divisions in the form of coordination and input from subordinates to superiors through intensive communication.

Supervision on budget implementation is done by Inspectorate of Batu City gradually every year in the form of regular inspection and incidental inspection if there is a direct report from the Mayor related to particular problem happens at local government agency (SKPD). The role of Inspectorate is to give an early warning system related to application of an activity in Kesbangpol office. Other than inspection, they also give development and supervision in doing main duties and functions, management of regional revenue, management of employment administration, and management of regional goods. The result of inspection is published into Audit Report $(L P H)$ that should be followed up by Kesbangpol office. The audit report published by Inspectorate for Kesbangpol office on 2013, 2014, and 2015 have been followed up, yet still have not been the priority because of several obstacles.

Monitoring is done to lessen deviation and improve effectiveness to accomplish organization's objectives. Based on the result of observation, interview, and documentation done by the researchers, continuous monitoring in Kesbangpol office helps smoothen evaluation 
process because monitoring makes budget implementation process works as it is planned. As mentioned by Siagian (2003:30) that monitoring is processes of observations from the all activities to ensure that all on-going works are in line with previously set plans.

\section{CONCLUSION}

Result of research and discussion within this research is SPIP on budget implementation has not been maximally implemented as what is written in Government Regulation No 60 Year 2008. That is depicted within unfulfilled elements of SPIP and incomplete supporting infrastructure of the system as written in Government Regulation No 60 Year 2008, Standard of Operation (SOP) of activities, and Office main duties and functions. The depiction of the SPIP's elements are: 1) Control area with its 8 sub-elements implemented as soft control is the most important element of SPIP. Control area forms human culture and behavior to build morality, ethics, integrity, honesty, discipline, skills, and commitment from all budget executor. In order to do the right performance, it has to be supported with adequate hard control. Minimum commitment of the superiors makes control area as written in Government Regulation No 60 Year 2008 become a main obstacle to create good control area. It is proven with incomplete job description for every head of divisions, no internal documentation and review from the superiors to the staff in Kesbangpol office related to their performance. 2) Risk assessment with 2 subelements, identification and analysis have been implemented, yet they have not been mapped and documented. 3) Activity control with its 11 sub-elements have been implemented, but the review is still limited on the order from related institutions. 4) Information and communication with its 2 sub-elements is the most effective means of communication to help budget implementation in creating accurate budget report. Budget report shown from this information and communication system is used as a source of evaluation to create improvement on future plan. However, the information system still needs to be repaired in order to provides enough information for treasurer assistant to operate SIMDA. 5) Monitoring with its 3 sub-elements has been implemented in order to lessen deviation in budget implementation and to improve the effectiveness in accomplishing its organization's objectives. However, recommended follow up from Government Internal Monitoring Officers (APIP) in this case is Inspectorate of Batu City has not been a priority. 
According to conclusion explained above, the suggestion that can be put forward in this research is The Government of Batu City needs to create supporting instrument for SPIP in the form of Regional Regulation as implementation regulation from Government Regulation No 80 Year 2008 about SPIP. The head of Kesbangpol office needs to immediately make Standard Operating Procedure (SOP) for every activity, main duties and functions of Kesbangpol office as a controlling tool for SPIP implementation. Other than that the Government also needs to create special unit for SPIP implementation in every Local Government Institution that have to guard SPIP to be well-implemented as written in Government Regulation No 8 Year 2008.

Kesbangpol office of Batu City also has to repair what have not been well-implemented. The elements that needs to be repaired are 1) element of control area in the form of superiors' strong commitment to establish job description for every staffs, so it can be used as an instrument to assess staff performance and also create internal documentation and review on staff performance. 2) In element of risk assessment, Kesbangpol office needs to map and document every possible risk in every activity as a source of evaluation to create future plan. 3) In the element of activity control, by doing internal review on staff performance before Inspectorate review. This internal review is estimated become a reference to evaluate in order to repair budget implementation in the next years. 4) Information and Communication that is applied through new innovations, the office needs immediately repair and realize formation of a political and intelligent information online system that can be accessed by related body, and 5) Monitoring element, the office needs to mind the recommendation and follow up monitoring by Government Internal Monitoring Officers (APIP) to get effective way to accomplish organization's objectives.

\section{REFERENCES}

Bastian, I. (2007). Sistem Akuntansi Sektor Publik. Jakarta. Salemba Empat.

Bastian, I. (2013). Sistem Pengendalian Manajemen Sektor Publik. Jakarta: Salemba Empat.

Committee of Sponsoring Organization of The Treadway Commission (COSO), (2013). Enterprise Risk Management-Integrated Framework, The Committee of Sponsoring Organizations of the Treadway Commission.

Committee of Sponsoring Organization of The Treadway Commission (COSO), (2009), Guidance on monitoring Internal control System-Integrated Framework.

Cresswell, J. W. (2014). Research Design: Qualitative, Quantitative, and Mixed Methods Approaches. Los Angeles: Sage Publications. 
Djohanputro, B. (2008). Manajemen Resiko Koorporat.Pendidikan dan Pembinaan Manajemen. Jakarta

Mahmudi. (2007). Manajemen Kinerja Sektor Publik, UPP STIM YKPN, Yogyakarta

Miles, M. B., dan Huberman, M. (2009). Analisis Data Kualitatif: Buku Sumber Tentang Metode-Metode Baru. Translated by Tjetjep Rohendi Rohidi. Jakarta: UI Press.

Moeller, R. R. (2007). COSO Enterprise Risk Management: Understanding the New Integrated ERM Framework. New Jersey: John Wiley \& Sons, Inc

Republik Indonesia, Decree of Minister of Home Affairs (Kepmendagri) 29 Year 2002 about Accountability and Supervision of Regional Revenue and Also Provincial Budget Preparation Guideline.

Republik Indonesia, Government Regulation No 58 Year 2005 about Management of Regional Revenue.

Republik Indonesia, Government Regulation No 60 Year 2008 about Government Internal Control System.

Republik Indonesia, Minister of Home Affairs Regulation No 13 Year 2006 about Guidelines of Internal Revenue Management.

Mayor of Batu City Regulation No 9 Year 2014 about Internal Control System on Goods/Services Procurement in Batu City Government.

Rizal, M., \& Khayati, S. D. (2011). Pemantauan Merupakan Alat Kendali Pada SPIP. Buletin Pengawasan, No. 85 Tahun 2011, ISSN 1470 - 1414, hal. 27-29.

Sedarmayanti. (2009). Reformasi Administrasi Publik, Reformasi Birokrasi, dan Kepemimpinan Masa Depan (Mewujudkan Pelayanan Prima dan Kepemerintahan yang Baik). Bandung: Refika Aditama.

Yuwono, S., et al. (2005). Penganggaran Sektor Publik: Pedoman Praktis Penyusunan, Pelaksanaan, dan Pertanggungjawaban APBD (Berbasis Kinerja). Malang: Bayumedia.

Yin, R. (2009). Case Study Research: Design and methods. Beverly Hills, CA: Sage.

Menpan.go.id (2015). [Online] http://www.menpan.go.id/reformasi-birokrasi/530-makna-dantujuan diakses pada tanggal 05 Agustus 2 